\title{
Forest Pathology for the Last Century: An Overview of the Symposium
}

\author{
J. A. Walla, W. R. Jacobi, and R. A. Schmidt
}

First author: Plant Pathology Department, North Dakota State University, Fargo 58105; second author: Bioagricultural Science \& Pest Management Department, Fort Collins 80523; and third author: School of Forest Resources and Conservation, University of Florida, Gainesville 32611.

Accepted for publication 7 March 2003.

Forest pathology in the United States is not an old discipline, with most of its practice having been in the 20th century. There were several truly dominating forest pathology stories in the United States in that century, some concerning devastating losses following pathogen introductions, others following changes in forestry practices, and some concerning subtle changes in our perception of microorganisms in forest ecosystems. A historical look at those stories, describing them and placing them into perspective, reflecting on our actions, and highlighting what was learned from years of research, was appropriate as we celebrated our past and looked to the future at the turn of the century. Using that retrospective can help us gain perspective for challenges in the 21 st century. The details of the various events are fascinating to those in the discipline, at least in part because they comprise our history. The importance, though, is that lessons be taken from past experiences so a better job can be done in the future.

In this light, the symposium "Forest Pathology for the Last Century: A Retrospective and Directions for the Future" was held at the 2000 annual meeting of The American Phytopathological Society (APS) in New Orleans, LA. It was sponsored by the APS Forest Pathology Committee. The organizing committee consisted of James Walla, William Jacobi, and Robert Schmidt. John Lundquist, U.S. Forest Service, obtained approval of and helped preside during the symposium. In just one symposium, even the most important problems and accomplishments of the last century could not be adequately revisited. The program provided little more than a snapshot of forest pathology in the 20th century, but the speakers addressed key issues of interest to all working in forest ecosystems.

The speakers for the symposium were J. A. Walla, W. L. MacDonald, R. L. Anderson, B. B. Kinloch, Jr., H. R. Powers, Jr., D. W. Fulbright, the late E. B. Smalley, P. D. Manion, and F. H. Tainter. J. A. Walla provided an introduction to the symposium. This was followed by two presentations that provided an overview of forest pathology in the 20th century. W. L. MacDonald made the keynote presentation, "Dominating North American Forest Pathology Issues of the 20th Century" (3). He reminded the

Corresponding author: J. A. Walla: E-mail address: j.walla@ndsu.nodak.edu

Publication no. P-2003-0602-010

(c) 2003 The American Phytopathological Society audience of the dominating stories (when, where, and why) and briefly described the situation as perceived at the time and now. R. L. Anderson presented "Changing Forests and Forest Management Policy in Relation to Dealing with Forest Diseases" (1). He described forests and forest management policy of the early $1900 \mathrm{~s}$ and how changes in those occurred and resulted in changes in the way we dealt with forest diseases through the century.

The second section of the symposium dealt with what happened in the 20th century with four individual diseases. The speakers and the diseases they dealt with were B. B. Kinloch, Jr., white pine blister rust (2); H. R. Powers, Jr., fusiform rust; D. W. Fulbright, chestnut blight; and the late E. B. Smalley, Dutch elm disease. These presentations provided a retrospective (what happened and what did we learn) and a direction (what are the challenges and opportunities for the future) involving specific, high-profile forest diseases. They described the losses that were incurred, the efforts undertaken, and the success and failures of those efforts. They focused on where we are at in terms of dealing with the diseases, what resources and information we now have that are key to future management, and what the needed steps in the 21 st century appear to be. Not all of these authors participated in the symposium proceedings. An additional paper involving fusiform rust was prepared by R. A. Schmidt (5) so that one of our best success stories in forest pathology would be included in the proceedings.

The final section of the symposium provided perspectives regarding forest pathology in the 20th century. P. D. Manion presented "Evolution of Concepts in Forest Pathology" (4), in which some of the foundation concepts of forest pathology that emerged in the 20th century were discussed with a current perspective. F. H. Tainter presented "Perspectives and Challenges from the 20th Century" (6), in which he provided perspectives on where we have been, where we are now, and where we are going in forest pathology.

It was clear during the symposium that forest pathology in the United States made substantial advances during the 20th century. Our base of knowledge of plant pathogens in forest ecosystems is now as good as anywhere in the world. Not all the wars were won; indeed, we know by now not to expect disease control, but rather to strive to make gains toward disease management. We learned that disease management is best done by prevention: prevention of pest introduction, prevention of losses by management or cultural means, and prevention by selection or breeding for resistance. We 
learned that management by ignoring the issues or by "locking up the forests" will not make the problems go away, but will instead exacerbate the problems.

The story is not yet complete for many of the forest disease epidemics of the 20th century. Little effective management has been developed for some of the diseases, and they continue to cause nearly unabated damage despite important discoveries that might be key to management in the future. For example, there has been extensive research involving white pine blister rust, but the disease is still spreading and causing severe damage in many situations. However, research involving deployment of resistance genes shows promise for reducing the severity of white pine blister rust epidemics. Some diseases were so damaging as to nearly eliminate dominant forest species, but new approaches to disease management hold the hope of at least partial restoration of these species. Chestnut blight has long since eliminated chestnut reproduction in the eastern United States, but recent research involving hypovirulent pathogen strains and breeding of hosts for resistance are showing promise that significant gains can be made to manage this disease. Some management opportunities for several highprofile forest diseases are being developed through molecular techniques using germ plasm collections and breeding work from decades ago. Indeed, most of our current efforts are built on the shoulders of our predecessors.

Examples of lessons that should be taken from past experiences are provided in the following papers. As forest pathologists and plant scientists in general, we have not done a very good job of keeping the gains that our discipline was able to make during the last century. The Dutch elm disease situation provides a good example. E. B. Smalley made the point that Dutch elm disease is an example of a disease that is close to being effectively controlled in our urban areas, but we are in danger of "snatching defeat from victory." Years of research were dedicated to developing elms that could be used to replace those lost to Dutch elm disease. However, those researchers that spent their careers to reach this goal are now retiring and their work is not being continued. Because the fungus that causes Dutch elm disease changes over time, as is true of most pathogens, Dr. Smalley felt it was critically important to continue the selection and breeding of elms if we are to have elms in our cities in the future. The downward trends in forest pathology research as shown in the paper by F. H. Tainter (6) provides the data to show that Dr. Smalley's concern regarding Dutch elm disease likely applies to forest pathology in general. This has and continues to occur for many programs, and is not isolated to germ plasm development programs.

As a discipline and as a society, our memory of what has gone on before us is not adequate, and that seriously damages our discipline and hinders reaching the goals that we strive for.
Another lesson that has not been learned by society is the importance of keeping exotic pests away from our forests. Notably, many of the dominating forest pathology stories of the 20th century involve introduced pathogens. Just as we must strive to hold onto our gains, we must do a better job of minimizing introductions of forest pathogens. The flow of exotic pests into the United States will not slow until we place high priority on identification of all threatening means of pest introduction and make dealing with those sources a real condition of all importation into the United States. This will require a very large increase in research, laws, enforcement, and penalties.

The future emphasis on and direction of forest pathology are in question or at least unclear as we begin the 21st century, but a retrospective assessment of the contributions of our discipline is wholly positive. Consider the magnitude of the tasks at hand, and then realize that the accomplishments made and lessons learned have been building through the 20th century. Although most forest disease epidemics have not been controlled, and there have been repeated and continuing exotic pathogen introductions into our forests, forest pathology has made tremendous strides, and it is far too pessimistic to conclude that nothing has been accomplished. For example, significant knowledge has been gained on (i) the biology and ecology of forest tree pathosystems, (ii) the nature and utility of genetic disease resistance in forest ecosystems, and (iii) the effective management of several important diseases. Forest pathologists can take pride in their emphasis on silviculturebased ecologically sound disease management. This emphasis and that on prevention of disease have, from the beginning, been a cornerstone of forest disease management. The past accomplishments of forest pathologists are commendable and now we must turn our attention to the future, however uncertain. Regardless of our outlook, we must continue to deal with forest health. Nothing less than our forests - a national heritage and important resourceare at stake. The perspectives and lessons that can be learned from the papers in these proceedings need to be part of that process.

\section{LITERATURE CITED}

1. Anderson, R. L. 2003. Changing forests and forest management policy in relation to dealing with forest diseases. Phytopathology 93:1041-1043.

2. Kinloch, B. B., Jr. 2003. White pine blister rust in North America: Past and prognosis. Phytopathology 93:1044-1047.

3. MacDonald, W. L. 2003. Dominating North American forest pathology issues of the 20th century. Phytopathology 93:1039-1040.

4. Manion, P. D. 2003. Evolution of concepts in forest pathology. Phytopathology 93:1052-1055.

5. Schmidt, R. A. 2003. Fusiform rust of southern pines: A major success for forest disease management. Phytopathology 93:1048-1051.

6. Tainter, F. H. 2003. Perspectives and challenges from the 20th century. Phytopathology 93:1056-1061. 